\title{
Impact of High Occupancy Vehicle (HOV) Lane Incentives for Hybrids in Virginia
}

David Diamond, Ph.D.

LMI Research Institute

\begin{abstract}
This paper examines the impact of Virginia's policy of exempting hybrid-electric vehicles from minimum occupancy requirements on state HOV lanes. Virginia registration statistics are used to compile hybrid market shares on a county level to compare the impact of HOV lane access to other socioeconomic variables. The HOV incentive is shown to have a significant impact in Northern Virginia, but not in the Hampton Roads area. The paper also addresses the criticisms and potential unintended consequences of the incentive policy, including whether it has impacted the "green" image of the hybrid in Virginia.
\end{abstract}

\section{Introduction}

This article examines the impact of HOV lane exemption policies for hybrid-electric vehicles, focusing primarily on the state of Virginia. Sales and general interest in Hybrid Electric Vehicles (HEVs) has risen steadily in recent years in response to rising fuel costs and increased concern about pollution and greenhouse gas emissions. Hybrid vehicles utilize the same gasoline fuel infrastructure as conventional Internal Combustion Engine (ICE) vehicles, yet represent a distinct technology improvement that can provide greater fuel economy and reduced emissions for equivalent vehicle performance by recapturing energy normally lost during break- 
ing (U.S. Department of Energy 2007). As an energy efficiency technology, HEVs also address positive externalities associated with resource management, the environment, and energy security, which are not taken into account by the market (Jaffe and Stavins 1994). In addition, HEVs face barriers to diffusion that are common to many new cost-saving technologies, such as high initial unit costs, lack of knowledge by potential adopters, high discount rates for future cost savings, and low consumer risk tolerance (Jaffe and Stavins 1994; Stoneman and Diederen 1994; Argote and Epple 1990). To account for these externalities and barriers to adoption, the U.S. Federal Government and many state governments have offered a variety of incentives and privileges to consumers who purchase hybrids and alternative fuel vehicles (U.S. Department of Energy 2007), one of the most notable being an exemptions from minimum vehicle occupancy requirements in High Occupancy Vehicle (HOV) carpool lanes. This privilege can result in considerable time savings for commuters who purchase hybrids.

Where HOV lanes exist and have sufficient excess capacity, allowing hybrids or alternative fuel vehicles on HOV lanes with a single occupant provides a means of promoting adoption with almost no direct marginal costs to taxpayers, other than the cost of publicizing, administering, and enforcing the program. Virginia was the first state to adopt this policy, starting in 2000, and since 2005 several other states, including Florida, Georgia, Utah, New York, New Jersey, California and Arizona, have allowed hybrids on at least some of the state's HOV lanes (U.S. Department of Energy 2007). Due to its seven-year history of allowing hybrids on HOV lanes, Virginia provides an excellent case study of the impact of HOV incentive policies for hybrids and may provide insights for other jurisdictions considering similar policy incentives. To that end, this paper examines the background of Virginia's HOV lane incentive and its impact on local adoption patterns. It compares the impact of Virginia's HOV lane policy to other potential determinants of hybrid vehicle adoption, including income, environmentalism, and commuting characteristics. Additionally, it looks at the potential for unintended consequences of the policy and whether there is evidence that HOV incentives have led to a backlash against the "green" image of hybrids in Virginia.

This paper builds on previous research into the determinants of hybrid vehicle adoption. Kahn (2007) found that environmentalism (as indicated by Green Party affiliation) was associated with hybrid ownership, based on regression analysis of census track-level data in six California cities. Heffner et al. (2005) conducted detailed interviews with households in Northern California that own HEVs and 
determined that both anticipated cost savings and the "green image" of hybrids influence purchase decisions. McManus and Berman (2005) analyzed the results of an online survey taken by 532 hybrid owners and 933 potential owners who visited the HEV information website HybridCars.com. Their report identified the desire to save money on gas and reduce pollution as significant motivating factors for purchasing a hybrid among both sets of respondents. A 2004 marketing survey by ChangeWave Research concluded that hybrid owners tend to be in the highest income demographics and are more sensitive to gas prices than environmental benefits in purchasing their vehicles (ChangeWave Research 2005).

Several more recent studies on hybrid vehicle adoption that also examine the impact of government incentives have been conducted using sales and registration data for U.S. states. Diamond (2008) conducted cross-sectional regressions of annual state market share for top-selling hybrid models using RL Polk registration data. The analysis found that average gasoline prices, income, miles traveled, and environmentalism were all positively related to market share, but that the presence or values of monetary incentives at the state level was generally weak or insignificant compared to these other factors. Gallagher and Muehlegger (2008) analyzed actual sales transaction data provided by JD Power and found a more significant impact from state incentives. However, both studies noted that sales tax waivers tended to be more significant than income tax credits, and that Virginia's HOV incentive appeared to have significantly impacted market share. This paper further contributes to the literature on incentive policies for hybrids by examining the impact of Virginia's HOV policy at the local level. It makes use of market share calculations for individual Virginia cities and counties to explore how the impact of the HOV incentive on hybrid adoption varied among different jurisdictions within the state, taking into account local variations in other factors such as income, environmentalism, and commuting habits.

\section{Virginia HOV System Background}

Virginia's incentive policy stems from a law predating the introduction of hybrids, which authorized the HOV lane exemption for a variety of alternative fuel vehicles. When hybrids were first introduced in the U.S. in 2000, the state Department of Motor Vehicles-under pressure from consumers and lawmakers-allowed hybrids (which run on gasoline and are therefore not technically alternative fuel vehicles) to also qualify for the program (Morrison and Counts 2005). Access to $\mathrm{HOV}$ lanes is controlled by issuing hybrids and other alternative fuel vehicles a 
"special clean fuel" license plate, which can be seen by police enforcing HOV rules. These plates provide single-occupant access to HOV lanes in two major areas: Northern Virginia, which boarders Washington, DC, and the Hampton Roads area, which includes Newport News, Norfolk, Chesapeake, and Virginia Beach. The Northern Virginia HOV lanes include three major highways-along Interstate Route 66 (I-66), the Dulles Toll Road (VA 267) and Interstate Route 95/395 (I-95/395). ${ }^{1}$ The law authorizing the exemption originally contained a two-year sunset clause, but until 2006 it was renewed for two additional years each time it had been set to expire. In 2006, lawmakers renewed the exemption for only one additional year, but ended single-occupant access for hybrids purchased after June 30,2006 , on the I- $95 / 395$ HOV lanes in response to concerns about overcrowding. In 2007 and 2008, the law was extended only on an annual basis; it is currently set to expire on June 30, 2009 (Virginia Department of Transportation 2008).

The map in Figure 1 shows the general locations of the Hampton Roads and Northern Virginia HOV networks. The map in Figure 2 shows the highways that make up the Northern Virginia HOV network.

On VA 267 and Interstate 66 (outside of 1-495), HOV lanes consist of the leftmost highway lane in each direction and are not physically separated from the rest of the highway. During the morning rush hours, these lanes are restricted to HOV-2 (two or more occupants required) in the inbound direction, switching to HOV-2 outbound during the evening rush hour. Along I-66 between 1-495 and the Washington, DC border, the entire highway is restricted to HOV-2 inbound in the morning (with non-HOV traffic permitted outbound only), and HOV-2 only for all outbound traffic in the afternoon (with non-HOV traffic permitted inbound). The most extensive HOV lane network is the 27-mile segment along Interstate 1-95/395. The 1-95/395 HOV lanes consist of a reversible two-lane segment that is separated from the main highway with limited access points, open to inbound (northbound towards Washington, DC) traffic in the morning and outbound traffic in the evening. Traffic is restricted to HOV-3 (three or more passengers required) during the morning and evening rush hours. Of these three HOV systems, the I-95/395 HOV lanes handle the most traffic and offer the most significant percentage time savings (approximately 50\%) compared to non-HOV traffic (Morrison and Counts 2005). Hampton Roads has HOV lanes on several of the main highways, but time savings and traffic volume on the HOV network are much lower than in Northern Virginia (The Marketing Source 2002). 


\section{Virginia HOV Areas}

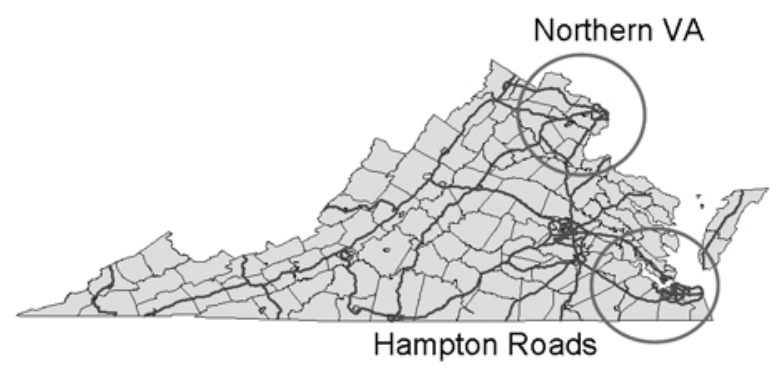

Figure 1. Virginia HOV lanes

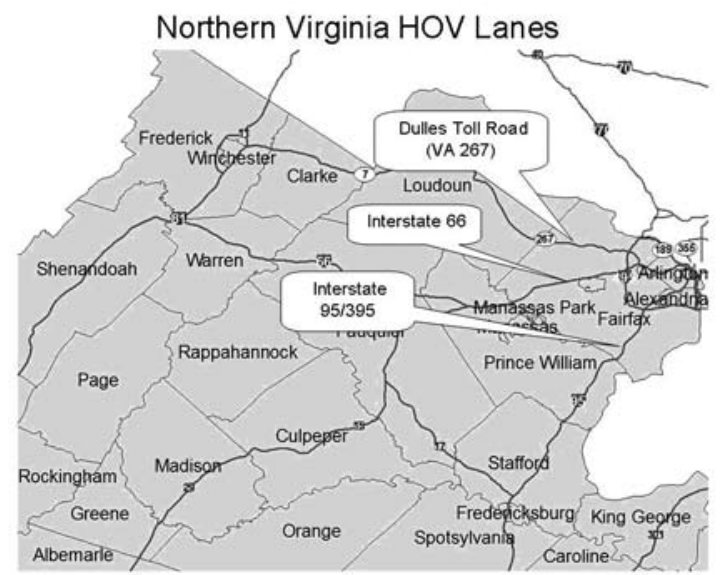

Figure 2. Northern Virginia HOV Lanes

\section{Criticism and Unintended Consequences}

Since its inception, Virginia's HOV exemption rule for hybrids has been the subject of considerable debate. Originally, the practice was in violation of Federal highway regulations for HOV lanes on interstate highways, which mandated that HOV lanes were only for high occupancy vehicles (Federal Highway Adminsitration 2005). This debate was ended by the Energy Policy Act of 2005, which authorized states to allow HOV exemptions for hybrids and other clean fuel vehicles. However, critics in newspaper editorials, opinion pieces, and internet discussion boards point out that the incentive policy runs counter to other policies designed to 
promote energy efficient practices such as carpooling and the use of mass transit (Ginsberg 2006). Some of the most vehement criticism of hybrid HOV drivers is found on discussion boards devoted to carpooling and ridesharing. One such message board, Slug-Line.com, contains over 2,800 mostly negative postings in 88 separate threads devoted to hybrids in the HOV lanes, with topics such as "hybrid hate," "anti-hybrid road rage," and "tired of choking on hybrid fumes."

One common complaint by critics is that single-occupant hybrid commuters in HOV lanes actually consume more gasoline per mile, on average, than carpoolers in less efficient vehicles with two or three passengers (Kuehnel 2006). By this criterion, hybrids would have to achieve a fuel economy of over $60 \mathrm{mpg}$ to justify access to the HOV lanes that normally require two vehicle occupants, based on an average fuel economy of $29.5 \mathrm{mpg}$ for passenger automobiles in 2006 (National Highway Transit Safety Administration 2006). This comparison may be partially valid, but the broader environmental impact of the policy is more difficult to determine and depends both on the percentage of hybrid drivers who would have commuted alone in the non-HOV lanes otherwise and the extent to which solo hybrid commuters also use their hybrids for non-commuting trips on evenings and weekends in place of less fuel efficient vehicles. Virginia has not conducted sufficient survey research to determine whether hybrid ownership has directly impacted carpooling or mass transit ridership in Virginia. However, a 2005 Virginia Department of Transportation Study concluded that hybrids accounted for 19 percent of traffic on the $1-95 \mathrm{HOV}$ corridor during the morning rush hour, and that this additional traffic had pushed the HOV lanes beyond their design capacity (Morrison and Counts 2005). It is likely that such increased congestion in the HOV lanes would serve as a disincentive to carpooling.

There is also an equity issue, since the HOV exemption policy favors those who not only can afford to buy a new car but can also pay the incremental premium to purchase a hybrid model over an equivalent gasoline-only model. While the availability of more affordable used hybrids should increase over time, Virginia Department of Motor Vehicles (DMV) records in May 2007 indicated that used vehicles still accounted for less than 15 percent of the total number of hybrids titled.

The combination of HOV lane overcrowding and backlash by carpoolers could potentially promote a more negative image of hybrid owners in Virginia, as compared to a generally positive image of hybrid owners in other parts of the country as environmentally-conscious consumers. To the extent that this phenomenon occurs, it may serve as a disincentive to consumers in the Northern Virginia area 
who do not desire HOV lane access but might otherwise have considered a hybrid for the positive environmental or "green" image it connotes.

The remainder of this paper addresses several basic research questions that arise from Virginia's experience with its HOV lane incentive. First, it explores whether the HOV incentive has been effective in promoting adoption of hybrids in Northern Virginia and Hampton Roads and how the effect of the policy compares to other socioeconomic factors. Second, it explores whether there is evidence that the policy has tarnished the "green" image of the hybrid in Virginia.

\section{Geographical Analysis of Virginia Adoption Patterns}

Statistics on new hybrid market share (new hybrids as a percentage of all new vehicles registered) for all Virginia counties and independent cities were used to test the impact of HOV lane policies in promoting adoption compared to other factors. The Virginia DMV provided basic data on every hybrid registered in the state as of May 31, 2007, including the automobile make, model, model year, original title date, and garaged jurisdiction (county or independent city). ${ }^{3}$ Using this database, the numbers of new and used hybrid vehicles titled in each county and independent city were calculated each year for Virginia Fiscal Years ${ }^{4} 2001$ through 2006 (FY01-06) and for the first three quarters of FY07. The DMV also provided a separate data set with the total number of new and used vehicles titled each fiscal year for each jurisdiction, which allowed the calculation of market share. The decision to analyze market share by fiscal year was driven primarily by the way that the DMV provided the data on total numbers of vehicles titled for each jurisdiction. However, the use of fiscal year was also convenient because it corresponded nicely with the change in the HOV policy for I-95/395 starting on July 1, 2006.

Figures 3 and 4 show the relative market share (given as a percentage) of new hybrids among counties in Northern Virginia and in the entire state, respectively, from FY01-06.

Figures 3 and 4 illustrate the dramatic difference in market share between counties adjacent to the Northern Virginia HOV lanes from those in the rest of the state. Stafford County, which includes the southern terminus of the I-95 HOV lanes, had the highest market share in the state for each individual year and for the combined period from FY01 through FY06. In FY06 (the year before the I-95/395 exemption ended), almost 6 percent of all new car registrations for Stafford County were for hybrid vehicles. Presumably, the high hybrid market shares in Northern Virginia 


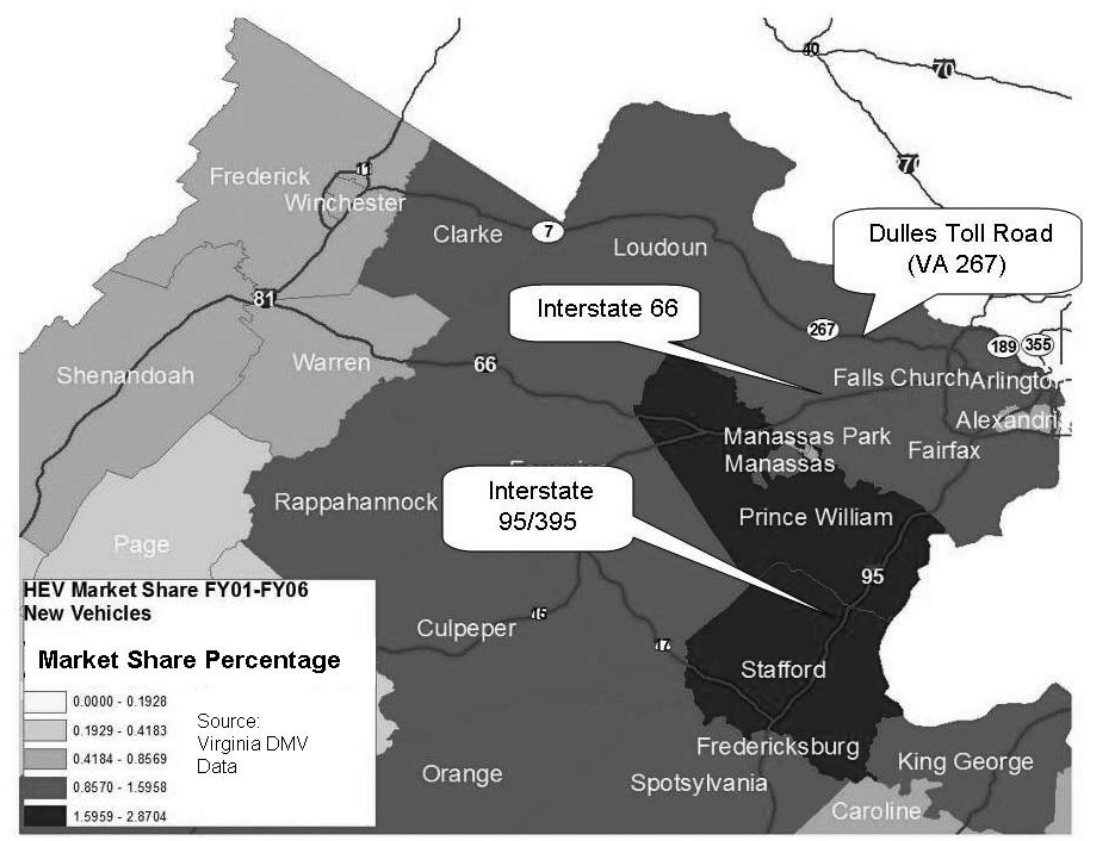

Figure 3. Hybrid (HEV) Market Share Percentages in Northern Virginia, FY01-06

HEV Market Share Percent

New Vehicles FY01-06

Market Share Percentage

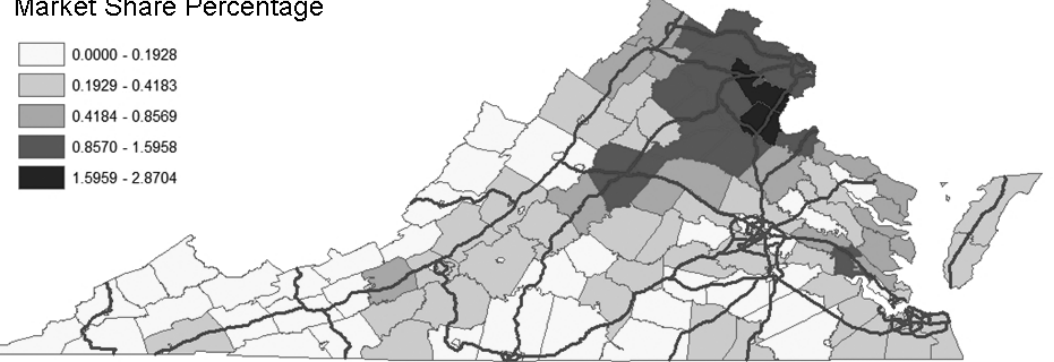

Source: Virginia DMV Data

Figure 4. Hybrid (HEV) Market Share Percentages in Virginia Counties, FY01-06 
are directly related to the time-savings value of the HOV exemption for commuters in these counties. The impressive market share in the Northern Virginia HOV corridors is in sharp contrast to lackluster market share in the remainder of the state. Despite the apparent impact of the HOV incentive policy in Northern Virginia, there is little graphical evidence that the policy impacted market share in the Hampton Roads area. This apparent discrepancy will be discussed further in the following sections.

It is important to note that the market share is based on new hybrids as a percentage of new vehicles, so this comparison already takes into account the fact that consumers in more affluent counties or cities are more likely to purchase new cars (versus used cars) than in less affluent jurisdictions. Figure 5 shows a geographical representation of market share percentages after correcting for income (dividing the market share by median county income), illustrating that the high market share for hybrids along the $1-95 / 395$ and $1-66 \mathrm{HOV}$ corridors is not strictly a function of higher consumer income in Northern Virginia.

\section{HEV Market Share Percent Normalized by Income New Vehicles FY01-06}

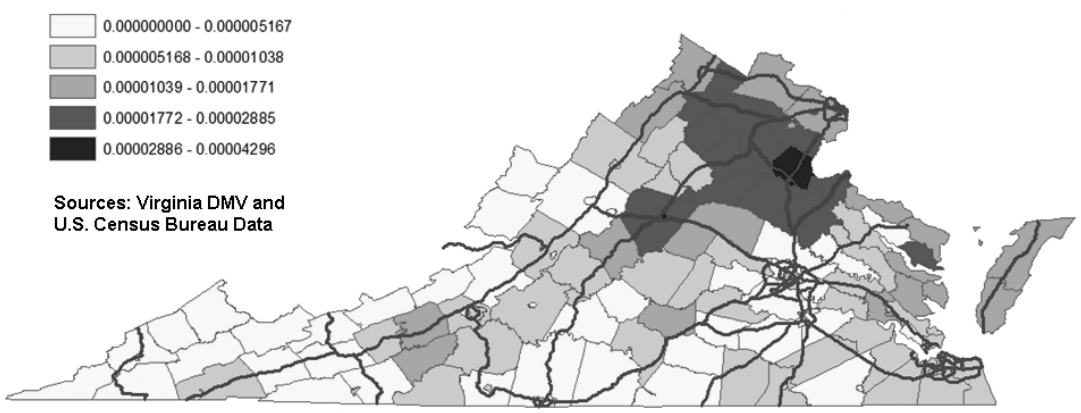

Figure 5. Hybrid (HEV) Market Share Normalized by Income, FY01-06

Another indication of the impact of the $1-95 / 395 \mathrm{HOV}$ exemption is the change in hybrid sales patterns in Northern Virginia after the exemption ended for hybrids purchased after June 30, 2006. Market share for the first nine months of FY07 dropped dramatically in Stafford and Prince William counties compared to FY06. The relative ratios of FY07 to FY06 sales in Virginia counties and cities are shown in Figure 6. 


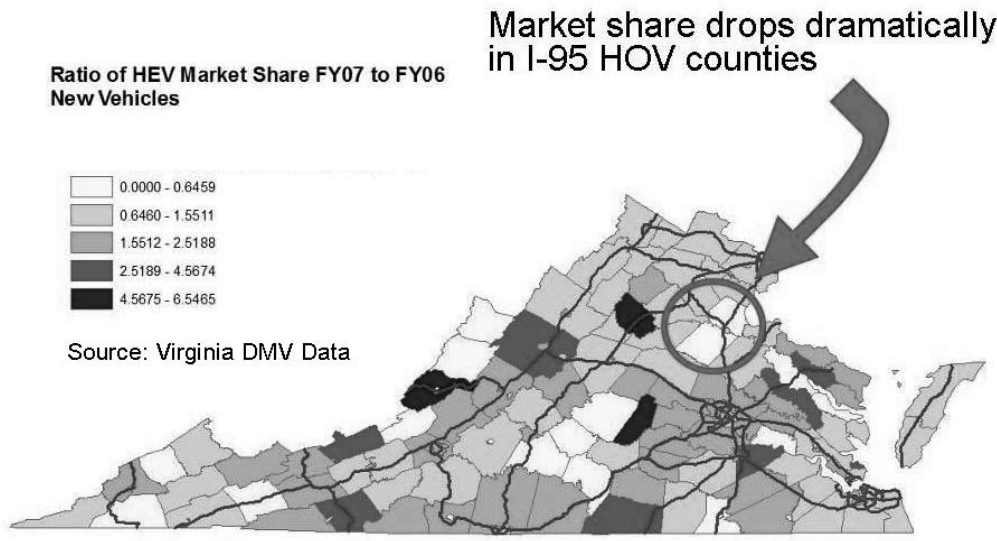

Figure 6. Ratios of FY07 to FY06 Hybrid (HEV) Sales

\section{Regression Analysis of Virginia Cities and Counties}

The significance of the HOV lane incentive compared to other socioeconomic determinants was explored further via cross-sectional regressions of annual market share of Virginia counties and independent cities. The basis for this cross-sectional methodology is described in Diamond (2008), where it is used to test for the significance of incentives using state aggregate market share. The significance of the presence of or close proximity to an HOV lane was tested, along with several other demographic variables for each county or city, using the following model specification:

$s_{h}=\alpha+\beta_{1}$ Income $+\beta_{2} \mathrm{HOV}_{\text {NOVA }}+\beta_{3} \mathrm{HOV}_{\mathrm{HR}}+\beta_{4}$ Green_Vote $+\beta_{5}$ Commute_Time $+\varepsilon$

This specification is extremely basic due to the limited amount of control data available at the local level. The percentage of votes for Green Party presidential candidate Ralph Nader in the 2000 presidential election was chosen as a proxy for environmentalism in the absence of a more direct local proxy such as the Green Planning Capacity Index used by Diamond (2008) or per-capita Sierra Club memberships used by Gallagher and Muehlegger (2008). However, the choice of Green Party votes is consistent with Kahn (2007), who uses Green Party registration percentages as a proxy for environmentalism. Because Virginia does not track individual party membership, actual election results were used instead. ${ }^{5}$

Mean commute time served as a proxy for relative commute distance, under the assumption that a further commute would provide a greater incentive to pur- 
chase a more fuel-efficient vehicle. Actual survey data on commute distance was not available at the county and city level for Virginia. While commute time proved significant in the regression, congestion may artificially inflate commute time for a given distance in urban areas.

Average gas prices proved significant at predicting hybrid market share at the state levels in previous studies (Diamond 2008; Gallagher and Muehlegger 2008), but it was difficult to incorporate gas prices into the Virginia analysis. Detailed historical average gas prices at the Virginia county and city levels were not readily available, although several services, such as Gasbuddy.com and VAgasprices.com, provide daily price data from a selection of gas stations within each locality. A county-level plot of daily gasoline prices from Gasbuddy.com on June 6, 2007, showed that average county gas prices varied between $\$ 2.82$ and $\$ 3.11$, with a standard deviation of only 4.5 cents per gallon (Gasbuddy 2007). However, variations between individual stations in the same county were almost as much as variations between county averages. In one attempt to use the June 6 county gas prices as a control, prices were statistically significant in some years, but with a negligible (and, in some cases, negative) effect. ${ }^{6}$

Table 1 provides a description of the variables and data sources.

\section{Table 1. Description of Variables for Virginia Hybrid Analysis}

\begin{tabular}{|c|c|c|}
\hline Variable & Description & Data Source \\
\hline$s_{h}$ & $\begin{array}{l}\text { Hybrid market share, expressed as } \\
\text { new hybrids as a percentage of all } \\
\text { new vehicle registrations for each } \\
\text { Virginia Fiscal Year (Virginia FY } \\
\text { starts in June) }\end{array}$ & $\begin{array}{l}\text { Virginia Department of Motor } \\
\text { Vehicles dataset of all hybrid } \\
\text { registrations and summary } \\
\text { statistics on county registrations } \\
\text { for each fiscal year }\end{array}$ \\
\hline Income & Median household income & $\begin{array}{l}\text { U.S. Census Bureau (Census of } \\
\text { Population and Housing 2000) }\end{array}$ \\
\hline Green_Vote & $\begin{array}{l}\text { Percentage of votes for Green } \\
\text { Party candidate Ralph Nader in the } \\
2000 \text { presidential election }\end{array}$ & $\begin{array}{l}\text { Virginia State Board of Elections } \\
\text { (Virginia General Election } \\
\text { Results 2000) }\end{array}$ \\
\hline Commute_Time & $\begin{array}{l}\text { Mean travel time to work in } \\
\text { minutes in } 2000\end{array}$ & $\begin{array}{l}\text { U.S. Census Bureau (Census of } \\
\text { Population and Housing 2000) }\end{array}$ \\
\hline $\mathrm{HOV}_{N V}$ & $\begin{array}{l}\text { HOV dummy for Northern } \\
\text { Virginia }\end{array}$ & $\begin{array}{l}\text { Virginia Department of } \\
\text { Transportation (VDOT) maps of } \\
\text { HOV lanes showing which } \\
\text { counties contain HOV lanes; } \\
\text { several adjacent counties were } \\
\text { also considered as HOV counties } \\
\text { based on the presence of HOV } \\
\text { park-and-ride lots and highways } \\
\text { that offered easy access to HOV } \\
\text { lanes in the adjacent county }\end{array}$ \\
\hline$H O V_{H R}$ & HOV dummy for Hampton Roads & DMV HOV maps \\
\hline
\end{tabular}


Table 2 provides a summary of the data used for each variable.

\section{Table 2. Summary of Variables for Virginia Hybrid Analysis}

\begin{tabular}{|l|c|c|c|c|c|}
\hline Variable & Obs & Mean & Std. Dev. & Min & Max \\
\hline FY01_Share & 133 & 0.024327 & 0.066077 & 0 & 0.4651 \\
\hline FY02_Share & 133 & 0.056624 & 0.107863 & 0 & 0.704 \\
\hline FY03_Share & 133 & 0.193483 & 0.350346 & 0 & 2.4666 \\
\hline FY04_Share & 133 & 0.306699 & 0.518211 & 0 & 3.1549 \\
\hline FY05_Share & 133 & 0.637115 & 0.732945 & 0 & 3.4594 \\
\hline FY06_Share & 133 & 1.222648 & 1.090285 & 0 & 5.9701 \\
\hline FY07_Share & 133 & 1.712782 & 1.250217 & 0 & 6.2796 \\
\hline HH Med Income 2000 & 132 & 39672.57 & 12169.61 & 22213 & 81050 \\
\hline Commute Time 2000 & 132 & 27.40076 & 6.61327 & 10.5 & 45.8 \\
\hline Green Party Vote 2000 & 133 & 1.958346 & 1.337182 & 0.22 & 9.04 \\
\hline HOV_NV FY 01-06 & 133 & 0.1278195 & 0.3351511 & 0 & 1 \\
\hline HOV_NV FY07 & 133 & 0.0902256 & 0.2875878 & 0 & 1 \\
\hline HOV_HR FY 01-07 & 133 & 0.0451128 & 0.2083362 & 0 & 1 \\
\hline
\end{tabular}

In FY07, the HOV dummy variable for Northern Virginia was adjusted to remove counties containing or adjacent to the 1-95/395 HOV lanes, where new hybrids were no longer entitled to single-occupant HOV lane access. Table 3 lists the counties represented by the HOV dummy variables.

\section{Table 3. Virginia HOV Counties and Cities ${ }^{7}$}

\begin{tabular}{|c|c|c|}
\hline $\begin{array}{l}H O V=N V \\
(F Y 01-06)\end{array}$ & $\begin{array}{c}\mathrm{HOV} \mathbf{N V} \\
(\mathrm{FY07})\end{array}$ & $\begin{array}{c}H O V_{-} H R \\
(A l l F Y s)\end{array}$ \\
\hline $\begin{array}{l}\text { Alexandria City } \\
\text { Arlington County } \\
\text { Caroline County } \\
\text { Clarke County } \\
\text { Fairfax City } \\
\text { Fairfax County } \\
\text { Falls Church city } \\
\text { Fauquier County } \\
\text { Fredericksburg City } \\
\text { Loudoun County } \\
\text { Manassas City } \\
\text { Manassas Park City } \\
\text { Page County } \\
\text { Prince William County } \\
\text { Spotsylvania County } \\
\text { Stafford County } \\
\text { Warren County }\end{array}$ & $\begin{array}{l}\text { Arlington County } \\
\text { Caroline County } \\
\text { Clarke County } \\
\text { Fairfax City } \\
\text { Fairfax County } \\
\text { Falls Church city } \\
\text { Fauquier County } \\
\text { Loudoun County } \\
\text { Manassas City } \\
\text { Manassas Park City } \\
\text { Page County } \\
\text { Warren County }\end{array}$ & $\begin{array}{l}\text { Hampton City } \\
\text { James City County } \\
\text { New Kent County } \\
\text { Newport News City } \\
\text { Norfolk City } \\
\text { Virginia Beach City }\end{array}$ \\
\hline
\end{tabular}

The regression was performed using an Ordinary Least Squares (OLS) specification. A Breusch-Pagan/Cook-Weisberg test for heteroskedasticity in STATA indicated significant heteroskedasticity problems for jurisdictions with higher marketshare. 
The presence of multiple zero values in the dependent market share variables (indicating jurisdictions that had no hybrids titled for that fiscal year) precluded the use of a log or Box-Cox transformation to reduce the effect. Instead, the results include heteroskedasticity-robust standard errors generated in STATA for the OLS regression. Table 4 lists regression results for each fiscal year.

Median household income, Green Party voting percentage, and mean commute time were statistically significant in explaining hybrid market share for all years except FY01. Of these three variables, Green Party voting percentage and household income had the strongest effects, with Beta coefficients increasing steadily each year from FY02 through FY06. In FY06, one standard deviation changes in Green Party voting percentage and household income were associated with .40 and .33 standard deviation changes, respectively, in new hybrid market share. In Northern Virginia, the HOV lane incentive was significant at the $p<.001$ level from FY02 to FY06, with Beta values between .3 and .5 for each year. After the incentive ended on 1-95/395 in FY07, the presence of the HOV lane incentive on 1-66 and VA-267 remains significant, although the Beta value dropped substantially, to .17. In Hampton Roads, there was no statistically significant relationship between HOV lane incentives and new hybrid registration for any year, which is consistent with the results of the geographic plot analysis in the previous section.

The strength and significance of Green Party voting percentage as a predictor of market share from FY05 onward also suggests that any "hybrid backlash" that may have occurred in Northern Virginia was not strong enough to erase the positive environmental image of the hybrid statewide. To further examine whether this theorized backlash actually occurred in Northern Virginia, regressions of market share versus income, commute time, and Green Party voting percentage were performed only for the 17 counties in Northern Virginia that were impacted by the HOV lane incentive (where the original HOV_NV dummy variable was equal to 1). Green Party voting percentage was insignificant until FY04, when it bordered on significance with Beta values greater than .5. In FY07, after the elimination of the incentive for new hybrids on 1-95/395, it became significant with a Beta value of .71. Thus, the trends in significance and strength of effect for the environmentalism proxy in Northern Virginia from FY04-FY07 are fairly consistent with the trends statewide from the original regression. A detailed results table for Northern Virginia is omitted. 
Journal of Public Transportation, Vol. 11, No. 4, 2008

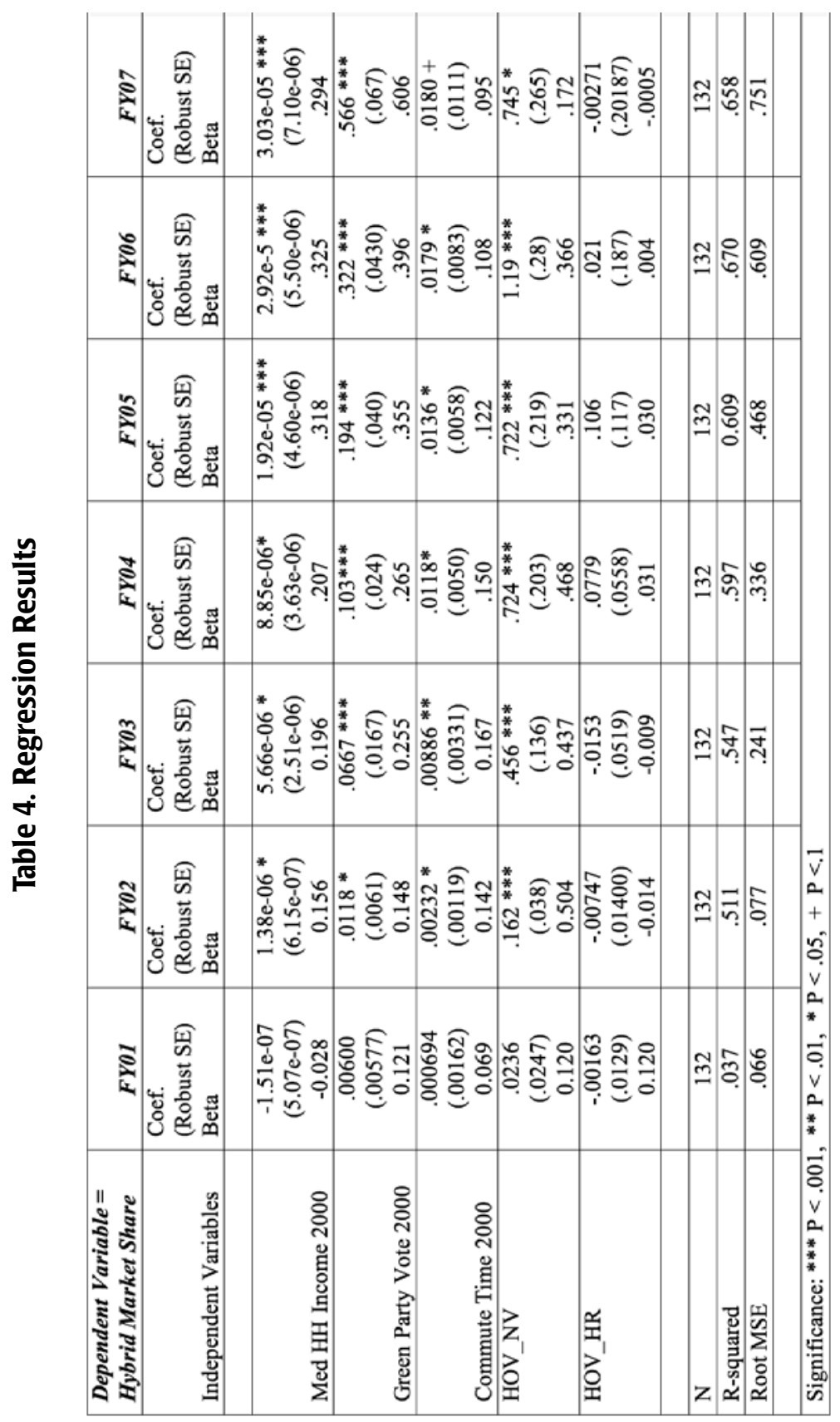




\section{Conclusions}

The geographic and regression analyses of hybrid registration patterns in Northern Virginia and Hampton Roads suggests that HOV lane incentive policies can significantly impact the adoption of hybrids by consumers, but only under specific circumstances. The geographic analysis shows that hybrid market share was highest along the 1-95/395 corridor-where HOV lanes offer the greatest time savings for commuters-but less dramatic on 1-66 and VA-267. Likewise, the Beta value for the Northern Virginia HOV dummy in the regression dropped sharply after the 1-95/395 corridor was excluded in FY07.

Surprisingly, the HOV incentive appears to have had no significant impact on hybrid vehicle market share in the Hampton Roads area. This may be due to a number of factors, but is most likely due to the nature of the local highway and HOV lane systems. While HOV lanes provide some degree of time savings in the Hampton Roads area, the overall traffic congestion and time saved are much less than on Northern Virginia highways. A 2002 study on attitudes about HOV lanes in the Hampton Roads area indicated that only 59 percent of Peninsula (Newport News and Hampton) and 76 percent of Southside (Norfolk and Virginia Beach) commuters felt that HOV lanes allowed commuters to reach their destinations faster than non-HOV lanes, compared to an almost universal appreciation of potential HOV time savings among Northern Virginia commuters (The Marketing Source 2002). Average distance traveled in the Hampton Roads HOV lanes was only 15 miles, compared to 25 mile HOV commutes in Northern Virginia, and much of the traffic congestion in Hampton Roads is actually the result of several narrow bridges and tunnels (none of which have HOV lanes) that connect neighboring counties. Additionally, the mean commute time for Hampton Roads HOV counties is significantly less than for Northern Virginia HOV counties-24.8 minutes versus 33.3 minutes-providing less of an incentive for adopting any time savings measure in the first place (U.S.Census Bureau 2000).

The significance of control variables for income, Green Party votes, and commute time is consistent with the theory and previous findings that individuals who have higher incomes and longer commutes and are more environmentally conscious are more likely to become early adopters of new vehicle efficiency technologies, ceteris paribus. In the case of HOV lane incentives, the effect of income may be amplified because the value of the time savings from HOV access is proportional to the value or utility that individuals place on their time. Therefore, individuals who earn more per hour might be likely to place a greater value on the incentive. 
The fact that Green Party voting percentage was the strongest and most signifcant predictor of market share from FY05 onward statewide and still significant in Northern Virginia (based on the separate Northern Virginia regressions), particularly in FY07, also suggests that any "hybrid backlash" that may have occurred did not erase the positive environmental image of the hybrid.

Even before FY07, the relative effect of Northern Virginia HOV lane access on market share had begun to decrease compared to other factors, perhaps in anticipation of the incentive's eventual expiration. The Beta values for the Northern Virginia HOV incentive peaked in FY04 then dropped each of the following years. Conversely, the Beta values for the coefficient of the household income variable increased from .21 in FY04 to .32 in FY05 and remained steady through FY07, while the Beta values for the Green Party voting percentage variable continued to increase, reaching a value of 61 by FY07.

The main findings of this research are that 1) Virginia's HOV lane incentive appears to have had a significant impact on hybrid vehicle adoption in Northern Virginia, but not in Hampton Roads; 2) the impacts of HOV incentive policies in general appear to be very sensitive to local conditions and the potential for time savings on a particular HOV corridor; and 3) the presence of the HOV incentive did not appear to diminish the impact of other factors-particularly environmental consciousness-on adoption of hybrid vehicles. While this paper looked specifically at Virginia, it is reasonable that evaluations of incentive policies in other states would highlight similar trade-offs between effectiveness, equity and unintended consequences.

Other states have already incorporated limitations into their own HOV policies. California limited the total number of solo HOV access permits to 85,000 to prevent overcrowding, although there is still anecdotal evidence that the policy has resulted in HOV lane congestion and sharply inflated prices that dealers charged for hybrids as the state neared the limit on permits (McKenzie 2007). Utah offers single passenger express lane access to all drivers willing to pay a $\$ 500$ per year fee, but charges hybrid owners only $\$ 50$ for the fee (U.S. Department of Energy 2007). While this may address the equity issue and help prevent any hybrid image backlash, it may also dampen the perceived utility of the incentive by explicitly limiting its value to $\$ 450$ per year. Other states have qualified HOV and other incentives with minimum gas mileage standards or periodic impact reviews.

Finally, an important consideration of the HOV exemption policy, compared to "one-time" incentives such as rebates or credits, is that it creates a small but 
extremely vocal group of "entrenched stakeholders" - hybrid owners-who have a significant personal stake in continuing the policy and are likely to fight strongly against any attempt to discontinue it by lawmakers or state agencies. Although this concern is common to all incentives that offer a continuing benefit over time, HOV access-more so than monetary incentives-may also influences residents' long-term decisions on where they live and work, encouraging choices that cannot be easily undone. Thus, the unique nature of the HOV incentive and the debate that the policy has caused in Virginia should give pause to other states considering similar programs. At the very least, policymakers would be wise to include feedback and data collection requirements into incentive legislation to help assess and manage the impact of incentive policies.

\section{Acknowledgement}

This paper is based on part of the author's Ph.D. Dissertation at the George Mason University School of Public Policy, which provided a generous portion of the funding for the data. The author would like to acknowledge dissertation committee chair Phil Auerswald; committee members David Hart, Chris Hill, Allison Macfarlane, and Peter Blair; three anonymous reviewers and numerous colleagues from $\mathrm{LMI}$ for their valuable advise and comments.

\section{Endnotes}

${ }^{1} \mathrm{I}-95$ becomes $\mathrm{I}-395$ between the 1-495 Beltway and the Washington, DC border.

${ }^{2}$ The term "slug line" refers to the anonymous ridesharing lines that form at several HOV park-and-ride lots in Northern Virginia. During rush hour, single drivers pick up anonymous passengers, known as "slugs," to gain access to the HOV lanes.

3 The data set excluded vehicles that were purchased in Virginia but removed from the state prior to May 2007. This may under-report the market share values slightly, but it is assumed that this trend affects all counties equally and does not affect the comparisons of market share between counties.

${ }^{4}$ The Virginia fiscal year runs from July 1 through June 30.

${ }^{5}$ The 2000 presidential election was chosen because of the strong Green Party showing (2.2\% statewide) compared to other years. 
${ }^{6}$ The negative gas price effect may be due to zone pricing strategies used by gasoline distributors set prices based in a manner that optimizes profits in specific geographic regions (Bayles 2001). While specific pricing strategies are held as trade secrets, prices are generally based on factors affecting demand such as commuting patterns and income. In the outlying Northern Virginia HOV counties where commuters have the choice of solo commuting, carpooling, or rail transport, prices may be kept lower to encourage automobile commuting and maintain demand. Since these suburban areas include the counties that benefit most from the HOV privileges, the zone pricing system may result in a spurious inverse correlation between gas prices and hybrid sales.

${ }^{7}$ Commute time was not provided for Alleghany County.

\section{References}

Argote, L., and D. Epple. 1990. Learning curves in manufacturing. Science 247 (4945): 920-924.

Bayles, F. 2001. Varying prices for gas leave drivers fuming. USA Today, August 14.

ChangeWave Research. 2005. Year of the Hybrid. 2004. Rockville: ChangeWave Research.

Diamond, D. 2008. PhD dissertation. Public policies for hybrid electric vehicles -The impact of government incentives on consumer adoption, School of Public Policy, George Mason University, Fairfax, VA. Available from http://hdl. handle.net/1920/2994.

Federal Highway Administration. 2005. Potential impact of exempt vehicles on HOV lanes.

Gallagher, K. S., and E. Muehlegger. 2008. Giving green to get green: Incentives and consumer adoption of hybrid vehicle technology. In John F. Kennedy School of Government Faculty Research Working Paper Series. Cambridge: Harvard University.

Gasbuddy. 2007. Virginia county gas price map, June 7 2007. Available from www. gasbuddy.com.

Ginsberg, S. 2006. Hybrid perks may become problems. Washington Post, February 14, B08. 
Heffner, R. R., K. S. Kurani, and T. S. Turrentine. 2005. Effects of vehicle image in gasonline-hybrid electric vehicles. Davis: UC Davis Institute for Transportation Studies.

Jaffe, A. B., and R. N. Stavins. 1994. The energy efficiency gap: What does it mean? Energy Policy 22 (10): 804-810.

Kahn, M. 2007. Do greens drive hybirds or hummers? Environmental ideology as a determinant of consumer choice. Journal of Environmental Economics and Management 54 (2): 129-145.

Kuehnel, P. 2006. Join the HOV club, but watch out for angry people. Green Mesh (June 15), http://greenmesh.com/2006/05/join_the_hov_club_but_watch_ ou.php.

The Marketing Source. 2002. HOV attitudinal research among Hampton Roads commuters. Chester, VA: The Marketing Source (for Virginia Department of Transportation).

McKenzie, R. B. 2007. Sticker shock. Opinion Journal - from The Wall Street Journal, February 19.

McManus, W. S., and B. Berman. 2005. 2005 O.S.A.T.-HybridCars.com survey of owners and shoppers. University of Michigan Transportation Research Institute.

Morrison, D. C., and M. Counts. 2005. Second report of the High-Occupancy Vehicle Enforcement Task Force: Virginia Department of Transportation.

National Highway Transit Safety Administration. 2006. New passenger car fleet characteristics.

Stoneman, P., and P. Diederen. 1994. Technology diffusion and public policy. The Economic Journal 104: 918-930.

U.S. Census Bureau. 2000. Census of Population and Housing. 2000. Washington, DC: U.S. Census Bureau.

U.S. Department of Energy. 2007. State and federal incentives and laws 2007. U.S. Department of Energy. Available from http://www.eere.energy.gov/afdc/ incentives_laws.html. 
U.S. Department of Energy. 2007. How hybrids work. U.S. Department of Energy (cited February 14 2007). Available from http://www.fueleconomy.gov/feg/ hybridtech.shtml.

Virginia Department of Transportation. 2008. HOV exemption for hybrid vehicles extended to June 30, 2009. Virginia Department of Transportation Press Release NR08-28 2008 (cited April 24 2008). Available from http://www.virginiadot.org/news/northern_virginia/2008/hov_exemption_for_hybrid.asp.

Virginia State Board of Elections. 2000. Virginia general election results.

\section{About the Author}

DAVID Diamond (ddiamond@lmi.org and ddiamond@gmualumni.org) is Research Fellow at LMI, a not-for-profit government consulting firm in Northern Virginia. He received his Ph.D. in Public Policy from George Mason University in 2008 and has a master's and BS degree in Mechanical Engineering from Rice University. He is also a submarine officer in the U.S. Navy Reserve. This paper is based in part on his Ph.D. Dissertation on public policies for hybrid-electric vehicles. 